Pesq. Vet. Bras. 34(Supl.1):7-10, dezembro 2014 DOI: 10.1590/S0100-736X2014001300002

\title{
Evaluation of bursal lymphoid depletion: comparison between the conventional histology method and digital lymphocyte depletion evaluation system ${ }^{1}$
}

\begin{abstract}
Carlos T.P. Salle², Lucas B. Moraes ${ }^{3 *}$, Francielli C. Zimermann ${ }^{4}$, Luiz C.B. Fallavena ${ }^{5}$, Fernando S. Osório ${ }^{6}$, Felipe O. Salle ${ }^{2}$, Daiane Carvalho ${ }^{2}$ and Hamilton L.S. Moraes ${ }^{2}$

ABSTRACT.- Salle C.T.P., Moraes L.B., Zimermann F.C., Fallavena L.C.B., Osório F.S., Salle F.O., Carvalho D. \& Moraes H.L.S. 2014. Evaluation of bursal lymphoid depletion: comparison between the conventional histology method and digital lymphocyte depletion evaluation system. Pesquisa Veterinária Brasileira 34(Supl.1):7-10. Instituto de Pesquisa Veterinária Desidério Finamor, Fundação Estadual de Pesquisa Agropecuária, Estrada Municipal do Conde 6000, Eldorado do Sul, RS 92990-000, Brazil. E-mail:lucasbmoraes@gmail.com

Fifty-five bursa of Fabricius (BF) were evaluated by optical microscopy for three different avian histopathologists ( $\mathrm{H} 1, \mathrm{H} 3$ and $\mathrm{H} 4)$ to determine the degree of lymphoid depletion. One histologist evaluated the same slides at two different times ( $\mathrm{H} 1$ and $\mathrm{H} 2$ ) with four-months interval between the observations. The same BFs were evaluated using the system of Digital Lymphocyte Depletion Evaluation (ADDL), being performed by three differents operators of the system, not histopathologists. The results showed was a significant difference between the histopathologists and between the scores established by the same expert (H1 and H2). However, there were not significant differences between the scores with the ADDL system, obtained using ADDL. The results make clear the fragility of the subjective lymphocyte depletion score classification by the traditional histologic method, while the ADDL system proves to be more appropriated for the assessment of the lymphoid loss in the BF.
\end{abstract}

INDEX TERMS: Depletion, bursa, image, histology, score.

RESUMO.- [Avaliação da depleção linfóide bursal: comparação entre a histologia convencional e o sistema de avaliação digital da depleção linfocitária.] Cinquenta e cinco bursas de Fabricius (BF) foram avaliadas através da microscopia óptica por três diferentes histopatologistas aviários (H1, H3 e H4) para determinar o grau de depleção

\footnotetext{
${ }^{1}$ Received on March 7, 2014.

Accepted for publication on November 3, 2014

${ }^{2}$ Centro de Diagnóstico e Pesqusias em Patologia Aviária (CDPA), Universidade Federal do Rio Grande do Sul (UFRGS), Av. Bento Gonçalves 8824, Porto Alegre, RS 91540-000, Brazil.

${ }^{3}$ Instituto de Pesquisa Veterinária Desidério Finamor (IPVDF), Fundação Estadual de Pesquisa Agropecuária (FEPAGRO). Estrada Municipal do Conde 6000, Eldorado do Sul, RS 92990-000, Brazil. *Corresponding author: lucasbmoraes@gmail.com

${ }^{4}$ Universidade Federal de Santa Catarina (UFSC), Rodovia Ulysses Gaboardi Km 3, Cx. Postal 101, Curitibanos, SC 89520-000 Brazil.

${ }^{5}$ Universidade Lutherana do Brasil (ULBRA), Rua Miguel Tostes 101, Canoas, RS 92420-280, Brazil.

${ }^{6}$ Instituto de Ciências de Matemática e Computação (ICMC), Universidade de São Paulo (USP), Av. Trabalhador São-Carlense 400, Cx. Postal 668, São Carlos, SP 13560-970, Brazil.
}

linfóide. Um histopatologista avaliou as amostras em dois momentos distintos (H1 e H2) com quatro meses de intervalo entre as observações. As mesmas BF foram avaliadas utilizando-se o sistema de Avaliação Digital da Depleção Linfocitária (ADDL), sendo realizadas por três diferentes operadores do sistema, não histopatologistas. Os resultados mostraram diferenças significativas entre os histopatologistas e entre um mesmo histopatologista (H1 e H2). Contudo, não houve diferenças significativas entre os escores obtidos utilizando-se ADDL. Estes resultados caracterizam a fragilidade da classificação subjetiva em escores de depleção linfóide, enquanto o sistema ADDL prova ser um sistema robusto de avaliação da perda linfocitária na BF.

TERMOS DE INDEXAÇÃO: Depleção, bursa, imagem, histologia, escore.

\section{INTRODUCTION}

The lymphoid depletion evaluation in the bursa of Fabricius is a broadly used tool to evaluate the poultry's immunological potential. Several conditions can lead to lymphocyte 
depletion, such as Gumboro disease [Eterradossi \& Saif 2008), mycotoxicosis (Hoerr 2008), chicken's infectious anemia (Schat \& van Santen 2008) and aggression of the environment (stress, bad hygiene and others) (Sellaoui et al. 2012).

The evaluation of the lymphocyte loss was always carried out in a subjective way until recently, relying only on the experience of the histologist in charge of it. However, this evaluation method produce distorted data and, in several cases, they are impossible to be compared. Many factors may lead to these distortions, such as the experience of the pathologist, the subjective criteria that each histologist uses to interpret the microscopic image or even a simple review of the histologic slides by the same histologist in different moments. Most of the research works that aim to evaluate the lymphoid depletion by this subjective way use scores or qualify the lesion in order to classify them (Chakraborty et al. 2010, Hadipour et al. 2011, Krishnamoorthy et al. 2007, Muskett et al. 1979. Raue et al. 2004). However, the utilization of subjective or personal terms such as "mild, moderate, severe or intense" is frequent and prevents to compare data. When using scores, the same problem occurs, as grading the lymphocyte loss is equally subjective and personal. The system of Digital Evaluation of Lymphoid Depletion (ADDL - Avaliação Digital da Depleção Linfocitária) was developed in order to minimize such distortions.

The ADDL system is a tool that uses the digital analysis of the image and artificial neural networks to establish the lymphoid depletion scores. This system was described by Moraes et al. (2010), who have compared the depletion scores that have been established through the conventional evaluation and the ones that have been done with the ADDL system. However, the variability in the scores done by different histologists has not been evaluated, as well as the use of the ADDL system applied by distinct operators. So, it was decided to characterize this variability through the comparison between the depletion scores established by three different histologists and the ones established by the ADDL system with three different operators.

\section{MATERIALS AND METHODS}

Histological sections of fifty-five Bursae Fabricii (BF) stained with hematoxylin and eosin, according Luna et al. (1968), have been analyzed through the subjective conventional method by an avian histopathologist (H1). These samples were from the laboratory routine, as a part of the slides storage. The samples were classified in to depletion scores that vary from 1 to 5 (score $1=$ depletion $<25 \%$; score 2 = depletion $25-50 \%$; score 3 = depletion 50 $75 \%$, score $4=$ depletion $75-90 \%$, and score 5 =depletion $>90 \%$ ). To reduce the risk of conditioning in the evaluation done by the histopathologist, the slides were numbered in a sequence from 1 to 55. Besides, each scores had numbers different of samples as follows: score $1=$ six samples, scores $2=15$ samples, score $3=$ 14 samples, score $4=10$ samples, and the score $5=10$ samples.

The histological sections have been evaluated another three times ( $\mathrm{H} 2, \mathrm{H} 3$ and $\mathrm{H} 4)$ by other three avian histopathologists with different background levels. The slides had to be evaluated for each one, just once, with no interruptions and in an ascending order. However, one of the histopathologists has evaluated the samples twice in different moments $(\mathrm{H} 1, \mathrm{H} 2)$, within four months

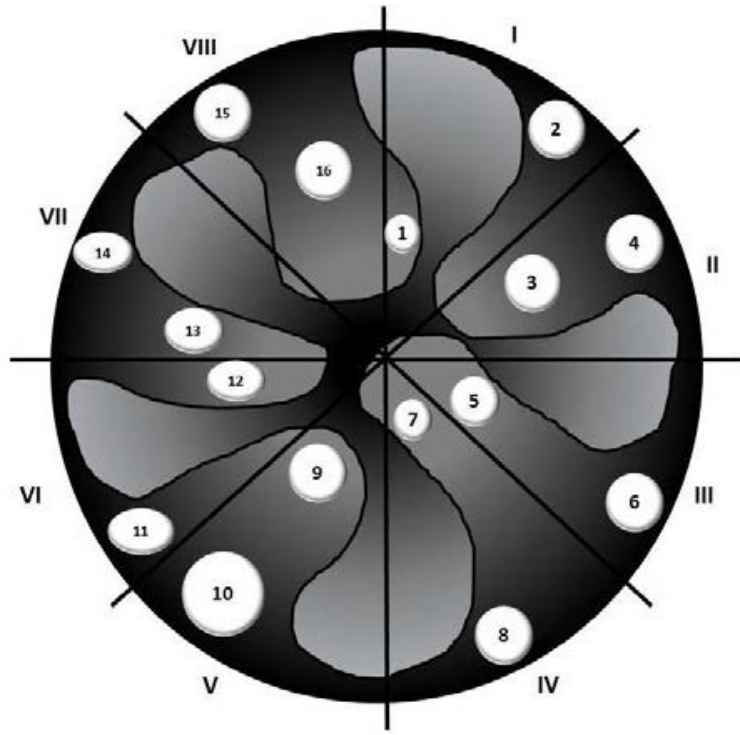

Fig.1. Illustrative image of the BF division (transversal section) into octants and samples of follicles.

between the evaluations, totalling four evaluations with the conventional method (H1, H2, H3 and H4). The evaluations with the ADDL system were carried out by the operators of the system (01, 02 and 03), who were undergraduate students with no experience in histopathology. Nevertheless, they were trained to use the Image digital processing system.

For the evaluation with the ADDL system each BF was divided into 8 parts (octants), (Fig.1) and two follicles per octant were selected at random in order to catch the images. The digital photomicrographs were obtained through the objective 20x in a trinocular Olympus Cx40 microscopy supported by an OLYMPUS C7070 digital camera. To obtain the images, aiming to guarantee the randomness in the selection of the follicles, the operators should blur completely the microscope, get into the octant area and adjust the microscope focus again. The follicle that was in the microscopic field would be the photographed one. The images processing was accomplished according described by Moraes et al. (2010). Each operator of the ADDL system has gone through all processing steps, from the division into octants to the images processing.

The data obtained from the images analysis was processed by the artificial neural networks system using the Neuroshell Classifier software, Ward Systems that have used the model that was previously generated (Moraes et al. 2010), which has classified the samples according to five depletion scores. The results obtained with the conventional analysis - subjective - were also compared between the histopathologists and the ones given by the ADDL system.

\section{RESULTS}

The data was analyzed by means of the Tukey-Kramer's test, where all classifications were compared with each other, as showed in Table 1.

It is possible to observe clear disagreements among the scores given by the histopathologists, except some exceptions as in the score 1 , which was uniform among these professionals, and in the score 4 , in which three out of four observations did not show significant variation. In the sco- 
Table 1. Comparison among scores by the histopathologists and by the operators of the ADDL system

\begin{tabular}{|c|c|c|c|c|c|c|c|c|c|c|}
\hline \multirow[t]{2}{*}{ Evaluator } & \multicolumn{2}{|c|}{ Score 1} & \multicolumn{2}{|r|}{ Score 2} & \multicolumn{2}{|r|}{ Score 3} & \multicolumn{2}{|r|}{ Score 4} & \multicolumn{2}{|r|}{ Score 5} \\
\hline & $\mathrm{n}$ & Average & $\mathrm{n}$ & Average & $\mathrm{n}$ & Average & $\mathrm{n}$ & Average & $\mathrm{n}$ & Average \\
\hline H1 & 6 & $1,00^{\mathrm{a}}$ & 15 & $2,00^{\mathrm{a}}$ & 14 & $3,00^{\mathrm{a}}$ & 10 & $4,00^{\mathrm{a}}$ & 10 & $5,00^{\mathrm{a}}$ \\
\hline $\mathrm{H} 2$ & 6 & $2,16^{a}$ & 15 & $3,00^{\mathrm{b}}$ & 14 & $3,71^{\mathrm{b}}$ & 10 & $4,40^{\mathrm{a}}$ & 10 & $4,70^{\mathrm{ab}}$ \\
\hline H3 & 6 & $2,16^{a}$ & 15 & $2,86^{b}$ & 14 & $3,71^{b}$ & 10 & $4,00^{\mathrm{a}}$ & 10 & $4,30^{\mathrm{b}}$ \\
\hline $\mathrm{H} 4$ & 6 & $1,50^{\mathrm{a}}$ & 15 & $2,06^{\mathrm{ac}}$ & 14 & $2,35^{c}$ & 10 & $3,10^{\mathrm{b}}$ & 10 & $4,10^{\mathrm{bc}}$ \\
\hline 01 & 6 & $2,00^{\mathrm{a}}$ & 15 & $2,81^{b}$ & 14 & $3,28^{\mathrm{ab}}$ & 10 & $3,26^{\mathrm{b}}$ & 10 & $3,60^{c}$ \\
\hline 02 & 6 & $2,01^{\mathrm{a}}$ & 15 & $2,76^{\mathrm{bc}}$ & 14 & $3,25^{\mathrm{ab}}$ & 10 & $3,30^{\mathrm{b}}$ & 10 & $3,60^{c}$ \\
\hline 03 & 6 & $1,91^{\mathrm{a}}$ & 15 & $2,78^{\mathrm{b}}$ & 14 & $3,32^{\mathrm{ab}}$ & 10 & $3,31^{b}$ & 10 & $3,58^{c}$ \\
\hline
\end{tabular}

Different letters in the same column indicates a significant difference $(\mathrm{p}=0.05)$.

re two, there was not an important difference among H2, $\mathrm{H} 3$ and all the operators. Also, there was not a significant difference between $\mathrm{H} 1$ and $\mathrm{H} 4$, but both were different from the other ones. For the score 3, although a significant difference has not been observed, both were quite different from $\mathrm{H} 1$ and $\mathrm{H} 4$. Among the samples with the score 5, significant differences had been observed between $\mathrm{H} 1, \mathrm{H} 3$ and the three operators. There were not differences among the classifications obtained by the three operators of the ADDL system.

\section{DISCUSSION}

In this study, the results clearly showed that the evaluations carried out by the histopathologists may be subjective, presented a high degree of subjectivity. It is worthy to mention that for the score 1 all professionals agreed with each other. It is possible that this was due either to the low number of samples in this group or to the fact that the characterization of a healthy tissue is easier to evaluate than the severity of the lymphocyte depletion in the BFs.

It was clear that the histopathologists disagreed significantly from each other for the other scores, usually forming two or three blocks. This variation is more evident in the score 3, it is an intermediate score and one of the responsible for the formation of a great gray zone of classification which still includes scores 2 and 4 . For scores 2 and 3, only two histopathologists have not presented an important difference in the classifications, being the other quite different among each other forming 3 different groups. The results have shown lack of criteria for the lymphoid depletion's classification once the histopathologists have had significant distinct results in most scores. The important differences showed in the scores obtained in the two readings by the same histopathologist (H1 and H2), observed mainly in the scores 2 and 3, may confirm this fact. Accordingly, it is possible to assume that the repeatability of the evaluations may not exist, turning vulnerable the comparison between the degrees of lymphocyte depletion among different groups in an experiment or, even more important, the comparison of the results obtained in distinct experiments. Rozina Murmu et al. (2014) used scores based in terms like apparently normal, mild, moderate and severe; to evaluate the pathogenicity and immunosuppressive properties of a Gumboro virus strain. Similar score ranking was used to Krishnamoorthy et al. (2007) for evaluate tha pathological effects the limphoid organs in broilers exposed to differents toxins. This kind of ranking makes difficult the repeatability of the experiment, mainly when is necessary the histopathologic results comparison. Similar In the case of periodical monitoring of flocks, the conventional method does not show enough reliability for the comparison among different samples evaluated in different times or by other pathologists.

However, the classifications carried out by the ADDL system did not showed significant differences when evaluating the lymphocyte depletion in the BFs examined. The results showed the accuracy of this system of analysis and provide data that allows to reproduces evaluations among an experimental group or, even, comparison between distinct experiments.

Besides, this work showed that, by using the ADDL system, the histopathologist will have more time to analyse other changes in the bursa of Fabricius, such as hemorrhage, inflammatory infiltration, presence of cysts, epitelial hiperplasia, etc.

\section{CONCLUSIONS}

There is common understanding among avian histopathologists that the subjectivity of the conventional histopathological method to evaluate the degree of lymphocyte depletion in the Bursa Fabricii may have an important influence in the results of the research.

It is shown that the ADDL system is more accurate and makes it possible to compare intra and inter-experiment results.

This system provides for the histopathologists more time to analyze other important changes in the bursas, as the task of evaluation of the lymphocyte loss may be carried out by less experienced people.

\section{REFERENCES}

Chakraborty P., Nath B.D., Islam R.M. \& Das P.M. 2010. Comparative susceptibility of fayoumi, indigenous and leghorn chicks to infectious bursal disease. ARPN J. Agricult. Biol. Sci. 5(6):27-34.

Hadipour M.M., Farjadian S.H., Azad F., Sheibani N. \& Olyaie A. 2011. Histologic lesions of thymus and bursa of Fabricius in commercial broiler chickens inoculated with H9N2 avian influenza virus. Int. J. Anim. Vet. Adv. 3(3):186-188.

Hoerr F.J. 2008. Mycotoxicoses, p.1197-1230. In: Saif Y.M. (Ed.), Diseases of Poultry. $12^{\text {th }}$ ed. Blackwell Publishing, Ames, Iowa.

Eterradossi N. \& Saif Y.M. 2008. Infectious bursal disease, p.185-208. In: Saif Y.M. (Ed.), Diseases of Poultry. $12^{\text {th }}$ ed. Blackwell Publishing, Ames, Iowa.

Krishnamoorthy P., Vairamuthu S., Balachandran C. \& Muralimanohar B. 2007. Pathology of Lymphoid Organs in Chlorpyriphos and T-2 Toxin Fed Broiler Chicken. Int. J. Poult. Sci. 6(1):71-76.

Luna L.G. 1968. Manual of Histologic Staining Methods of the Armed Forces Institute of Pathology. $13^{\text {th }}$ ed. McGraw-Hill, New York. 258p.

Moraes L.B., Osório F.S., Salle F.O., Souza G.F., Moraes H.L.S., Fallavena L.C.B., Santos L.R. \& Salle C.T.P. 2010. Evaluation of follicular lymphoid depletion in the Bursa of Fabricius: an alternative methodology using digital image analysis and artificial neural networks. Pesq. Vet. Bras. $30(4): 340-344$. 
Muskett J.C., Hopkins I.G., Edwards K.R. \& Thornton D.H. 1979. Comparison of two inectious bursal disease vaccine strains: efficacy and potential hazards in susceptible and maternally immune birds. Vet. Rec. 104:332-334.

Raue R., Islam M.R., Islam M.N., Badhy S.C., Das P.M. \& Müller H. 2004. Reversion of molecularly engineered, partially attenuated, very virulent infectious bursal disease virus during infection of commercial chickens. Avian Pathol. 33(2):181-189.

Rozina Murmu R., Islam M.N., Juli M.S.B., Khan M.A.S., Rashid S.M.H., Hos- sain F.M.A. \& Rahman M.M. 2014. Pathogenicity and immunosuppressive properties of GM-97 strain of infectious bursal disease virus in commercial broiler chickens. J. Adv. Vet. Animal Res. 1(1):1-7.

Schat K.A. \& van Santen V.L. 2008. Chicken Infectious Anemia, p.211-235. In: Saif Y.M. (Ed.), Diseases of Poultry. $12^{\text {th }}$ ed. Blackwell Publishing, Ames, Iowa.

Sellaoui S., Alloui N., Mehenaoui S. \& Djaaba S. 2012. Evaluation of Immune Status of the Chicken using Morphometry and Histology of the Bursa of Fabricius. J. Vet. Adv. 2(8):440-443. 